\title{
Age-related Variations in Anthropometry, Body Composition and Nutritional Status among the Adult Kheria Sabar Males of Purulia, West Bengal, India
}

\author{
Kaustav Das $^{1}$, Koel Mukherjee ${ }^{2}$, Sayak Ganguliª ${ }^{3}$, Somosree Pal'1, Subrata Sankar Bagchi ${ }^{1}$ \\ ${ }^{1}$ Department of Anthropology, Bangabasi College, India \\ 2 Anthropological Survey of India, Andaman \& Nicobar Regional Centre, Port Blair, India \\ ${ }^{3}$ Department of Biotechnology, St. Xavier's College (Autonomous), Kolkata, West Bengal, India
}

\begin{abstract}
A B S T R A C T
Undernutrition and ageing may have a significant effect on body composition. A cross sectional study was conducted to explore the age-related variations among different anthropometric and body composition characteristics amongst the adult Kheria Sabar males of Purulia district of West Bengal. From fifteen villages, 304 apparently healthy adult males aged 18-60 years were selected at random. Subjects were categorized into four age groups and standard anthropometric measurements were used like height (HT), weight (WT), mid-upper-arm circumference (MUAC) and skinfolds of biceps (BSF), triceps (TSF) and sub-scapular (SSSF) region. Derived variables of body mass index (BMI), per cent body fat $(P B F)$, fat mass (FM), fat-free mass (FFM), fat mass index (FMI) and fat-free mass index (FFMI) were also calculated. Majority of the variables were found to be inversely correlated with age. Positive (HT, WT, MUAC, BMI, FFM and FFMI) and negative (FM and FMI) significant differences were observed across different age groups. It was also observed that the frequency of undernutrition (62.6\%) was the highest among the elderly people with $47.6 \%$ overall prevalence. This study clearly indicates that among the undernourished individuals, older people were more vulnerable to malnutrition and thus immediate nutritional intervention is required.
\end{abstract}

Key words: anthropology, Kheria Sabar, undernutrition, age variation, body composition

\section{Introduction}

Proper nutrition is fundamental to good health and development over prolonged periods which are reflected in components of body composition. Gender, age, nutrition, physical activity and hormonal status are main determinants of body composition among healthy adults. As a whole, body composition can be viewed from five perspectives: atomic, molecular, cellular, tissue and the whole body level; and there is a complex interaction between the molecules and the system ${ }^{1}$. Undernutrition may have a significant effect on body composition as it develops when the nutritional intake falls short of nutritional requirements, results in organ dysfunction, reduced body cell mass, abnormal blood chemistry and worsened clinical outcomes ${ }^{2}$.

Various models are used to assess body composition like two-compartment (2C), three-compartment (3C), four-compartment (4C) or multi-compartment models ${ }^{3}$. Anthropometric measurements like circumferences and skinfolds on different body parts along with body weight and height are widely used to predict body composition for all age groups ${ }^{4-6}$. These measurements are very simple to measure, do not require high technical skills, they are inexpensive and need minimal sets of equipment in remote field areas and have become popular among researchers worldwide ${ }^{7-9}$. The simplest approach in body composition is dividing the body weight into fat mass (FM) and fat-free mass (FFM) ${ }^{3}$. Several researchers have subsequently reported the widespread use and importance of using percentage body fat (PBF), FM, FFM, fat mass index (FMI) and fat-free mass index (FFMI) as components of body composition ${ }^{10-14}$. 
Ageing is an important factor associated with substantial changes in body composition as reductions in FFM as well as increases in FM related to the accumulation of adipose tissue, particularly in the abdominal region occur during ageing ${ }^{15}$. A comparative study ${ }^{16}$ between Asians and Caucasians has shown that body composition and its age-related changes have a strong genetic component. Some external factors such as social environment and physical activities also influence body composition ${ }^{17}$. For the prevention of morbidity and risk assessment of mortality, studying changes in body composition with ageing may be used as a pre-diagnosis tool.

In India, the neonatal mortality rate is 43 per 1000 live birth ${ }^{18}$. There are several possible reasons for this and one of them is inadequate nutrient intake both in mother and children. Undernutrition influences the growth and development of those children who survive in their infancy but are later exposed in adulthood to risks for several diseases. Studies on large scale health research in India are mostly conducted on undernourishment among women, infants and children and rarely among adults ${ }^{19}$. A study based on the data of the National Family Health Survey-3, indicates that $28.6 \%$ of Indian men are underweight ${ }^{20}$. Tribal people in India constitute $8.6 \%$ of the total population and socially as well as economically they are the most underprivileged section of the society ${ }^{21}$. Studies on their health status are insufficient compared to those on other sections of Indian society, especially among adult males, though few studies have highlighted on the frequency of undernutrition and associated anthropometric and body composition characteristics in relation to age among this vulnerable population ${ }^{8-9,22-23}$. A review based on 76 studies on different tribal populations of India revealed that both tribal males (49.3\%) and females (52.0\%) were considerably undernourished ${ }^{21}$. Kshtriya and Acharya $^{24}$ in their study on nine major Indian tribes reported an overall prevalence of undernutrition among tribal males of $32.1 \%$.

Kheria Sabar is one of the most backward tribal communities in West Bengal, traditionally living in deep jungles and in general they identify themselves as Sabar ${ }^{25}$. During the British period they were labeled as "Criminal Tribe". After the sixty years of independence, they still have to carry the stigma of criminality ${ }^{26}$. Apart from $\mathrm{Pu}$ rulia, they are mostly distributed in the districts of Jhargram, Paschim Medinipur, Purba Medinipur, Bankura and Jalpaiguri of West Bengal. They live in small hamlets comprised of 20 to 30 households. Most of them are living in mud houses and only a few got brick-built government houses under the central government housing scheme. These people are from very low socio-economic stratum depending predominantly on daily wage labor. Their level of education is very low as most of them remain illiterate. Most of the households do not have a separate kitchen and proper toilet facilities. Interestingly, a large portion of their daily diet depends on locally available forest resources. Consumption of alcohol is very high among them.

To the best of our knowledge this is the first attempt to explore age-related variations among different anthro- pometric and body composition characteristics to get some insight into the larger issue of physical consequences of undernutrition among the adult Kheria Sabar males of Purulia, West Bengal, India.

\section{Materials and Methods}

This cross-sectional study was conducted from September 2019 to January 2020 on adult Kheria Sabar males aged 18-60 years from western-most Purulia district of West Bengal, India. Fifteen villages from four administrative blocks namely Purulia-I, Puncha, Manbazar-I and Bandwan were selected for this study. For the purpose of this study, 304 apparently healthy adult Kheria Sabar males were selected based on their availability during the study period on a random basis. Prior ethical clearance (No. 002/2017) was obtained from Research and Ethics Committee of Bangabasi College, University of Calcutta, Kolkata, West Bengal. Necessary permissions were obtained from the local administration and community leaders before the commencement of the study. Subjects were also informed about the objectives of the study and the informed consent was obtained before data collection.

All anthropometric measurements were taken by using calibrated instruments and following the standard proto$\mathrm{col}^{7}$. Measurements like height $[(\mathrm{HT})(\mathrm{cm})]$ was measured by Martin's anthropometer rod, weight [(WT) (kg)] by digital weighing machine (Omron HN 289); calibrated non-elastic measuring tape (Gulick Anthropometric Tape) was used to measure mid-upper-arm circumference [(MUAC) (cm)] and skinfold caliper (Slim Guide Skinfold caliper) for biceps skinfold [(BSF) (mm)], triceps skinfold [(TSF) (mm)] and sub-scapular skinfold [(SSSF) (mm)]. HT and MUAC measurements were recorded to the nearest $0.1 \mathrm{~cm}$ and WT was recorded to the nearest $0.5 \mathrm{~kg}$. Technical errors of measurements were found to be within the acceptable limit ${ }^{27}$. Derived variables like Body Mass Index (BMI), Percent Body Fat (PBF), Fat Mass (FM), Fat-Free Mass (FFM), Fat Mass Index (FMI) and FatFree Mass Index (FFMI) were calculated following standard formulae:

$$
\begin{aligned}
& \text { BMI }\left(\mathrm{kg} / \mathrm{m}^{2}\right)=\text { Weight }(\mathrm{kg}) / \text { Height }\left(\mathrm{m}^{2}\right) \\
& \text { PBF }(\%)=(1.20 \times \mathrm{BMI})+(0.23 \times \text { Age })-(10.8 \times \mathrm{Sex})- \\
& \text { 5.4, where, Sex; Male }=1^{12} . \\
& \mathrm{FM}(\mathrm{kg})=\text { Body Weight }(\mathrm{Kg}) \times[\mathrm{PBF} / 100]^{11} . \\
& \mathrm{FFM}(\mathrm{kg})=[\text { Body Weight }(\mathrm{Kg})-\mathrm{FM}(\mathrm{Kg})]^{28} . \\
& \text { FMI }\left(\mathrm{kg} / \mathrm{m}^{2}\right)=\left[\mathrm{FM}(\mathrm{Kg}) / \mathrm{Height}\left(\mathrm{m}^{2}\right)\right]^{11} \cdot \\
& \text { FFMI }\left(\mathrm{kg} / \mathrm{m}^{2}\right)=\left[\mathrm{FFM}(\mathrm{Kg}) / \text { Height }\left(\mathrm{m}^{2}\right)\right]^{13} \cdot \\
& \text { WHO }{ }^{29} \text { Asia Pacific cut-offs were used to access under- }
\end{aligned}
$$
nutrition.

Collected data were analyzed using SPSS version 16.0. Subjects were categorized into four age groups: Group. I: 18-27 years $(\mathrm{N}=78)$, Group. II: $28-39$ years $(\mathrm{N}=78)$, Group. III: $40-49$ years ( $\mathrm{N}=73)$, and Group. IV: $\geq 50$ years $(\mathrm{N}=75)$. Descriptive statistics was used to find out mean, standard deviation, minimum, maximum and percentile values of all the anthropometric and derived variables. 
One-way ANOVA was performed to test for age group differences among the mean of anthropometric and derived variables. Multiple Comparison Test (Scheffe's Post-hoc test) was used to determine between and within age group variations of those anthropometric characteristics which were found to be statistically significant in one-way ANOVA test. Pearson correlation was used to find out the linear association between the variables of interest. Linear regression analysis was also used to see the effect of age on the anthropometric variables. A probability value of $<0.05$ was considered statistically significant.

\section{Results}

Table 1 shows the descriptive statistics of age, anthropometric and derived variables of the studied population. It provides the means $( \pm \mathrm{SD})$ of anthropometric variables like age, HT, WT, MUAC, BSF, TSF and SSSF and those of the derived variables BMI, FMI and FFMI. Range of values and $25^{\text {th }}, 50^{\text {th }}$ and $75^{\text {th }}$ percentile values of each variable are also presented in the table.

Table 2 demonstrates age trends in anthropometric and derived variables (Mean \pm SD) of the participants. Significant age group differences $(\mathrm{p}<0.05)$ can be observed among all the derived variables and anthropometric variables except for skinfolds. There is a trend of decreasing mean values of most of the variables with increasing age. The results revealed that age Gr. I had higher mean values of WT (51.3 \pm 6.8$)$, MUAC (24.8 \pm 2.1$)$, BSF (3.0 \pm 1.0$)$, TSF (6.1 \pm 2.9$)$ and SSSF (9.4 \pm 3.8$)$ compared to other age groups. Males of Gr. II had the highest mean values for HT $(161.8 \pm 5.0)$ of all four age groups. BMI $(\mathrm{F}=6.316$, $\mathrm{p}<0.05), F F M(\mathrm{~F}=39.860, \mathrm{p}<0.05)$ and FFMI $(\mathrm{F}=43.853$, $\mathrm{p}<0.05)$ show a gradual decrease of mean values from $\mathrm{Gr}$. I to IV while PBF $(\mathrm{F}=71.378, \mathrm{p}<0.05), \mathrm{FM}(\mathrm{F}=12.526$, $\mathrm{p}<0.05)$ and FMI $(\mathrm{F}=14.262, \mathrm{p}<0.05)$ exhibit a reverse trend (from Gr. IV to I).

As the performed one way ANOVA analysis did not reveal variances between the variables, Multiple Comparison Test (Scheffe's Post-hoc test) was applied for group comparison of anthropometric characteristics, between/ within four age groups and presented in Table 3. Only those variables which showed significant $(p<0.05)$ values in one-way ANOVA test were considered in Scheffe's Posthoc test. Negatively significant differences were observed for PBF among all age groups and for FM and FMI between I vs. II, I vs. IV and II vs. IV group. Similarly, positively significant differences were observed for WT (except I vs. II, I vs. III and II vs. III), MUAC (except I vs. II, II vs. III, II vs. IV and III vs. IV), BMI (except I vs. II, I vs. III, II vs. III and III vs. IV), FFM (except I vs. II) and FFMI (except II vs. III) among different age groups. Since few variables show insignificant statistical relationship it is safe to assume that the detected variability may be attributable to other factors currently not under the purview of this study.

The results of the correlations between different variables presented in Table 4 reveal that except for age and HT, all other variables had significant correlation between them. Age had a significantly negative correlation with WT

TABLE 1

DESCRIPTIVE STATISTICS OF AGE, ANTHROPOMETRIC AND DERIVED VARIABLES OF THE PARTICIPANTS

\begin{tabular}{|c|c|c|c|c|c|c|c|}
\hline \multirow{2}{*}{ Variables } & \multirow{2}{*}{ Mean } & \multirow{2}{*}{$\mathrm{SD}$} & \multirow{2}{*}{ Minimum } & \multirow{2}{*}{ Maximum } & \multicolumn{3}{|c|}{ Percentile } \\
\hline & & & & & 25 th & 50 th & 75 th \\
\hline \multicolumn{8}{|c|}{$\mathrm{N}=304$} \\
\hline Age (yrs) & 38.7 & 12.9 & 18.0 & 60.0 & 27.0 & 39.0 & 49.0 \\
\hline Height $(\mathrm{cm})$ & 162.2 & 5.3 & 140.5 & 176.0 & 159.2 & 161.9 & 165.5 \\
\hline Weight (kg) & 49.7 & 6.5 & 35.0 & 74.1 & 45.8 & 49.3 & 53.1 \\
\hline MUAC (cm) & 24.0 & 2.2 & 18.0 & 31.0 & 22.5 & 23.9 & 25.3 \\
\hline $\mathrm{BSF}(\mathrm{mm})$ & 2.9 & 0.9 & 1.00 & 7.0 & 2.0 & 3.0 & 3.0 \\
\hline $\mathrm{TSF}(\mathrm{mm})$ & 5.9 & 2.3 & 2.0 & 17.0 & 5.0 & 5.0 & 6.0 \\
\hline $\operatorname{SSSF}(\mathrm{mm})$ & 8.9 & 3.3 & 3.0 & 26.0 & 7.0 & 8.0 & 10.0 \\
\hline BMI (kg/m2) & 18.8 & 2.2 & 13.2 & 28.4 & 17.4 & 18.6 & 20.0 \\
\hline PBF (\%) & 15.3 & 3.4 & 7.8 & 27.5 & 12.8 & 15.3 & 17.5 \\
\hline FM (kg) & 7.7 & 2.4 & 3.1 & 20.4 & 6.1 & 7.5 & 8.8 \\
\hline FMI (kg/m2) & 2.9 & 0.9 & 1.2 & 7.8 & 2.3 & 2.8 & 3.3 \\
\hline FFM (kg) & 42.0 & 4.8 & 30.0 & 58.4 & 38.7 & 41.8 & 44.9 \\
\hline FFMI (kg/m2) & 15.9 & 1.5 & 11.6 & 21.3 & 14.9 & 15.8 & 16.7 \\
\hline
\end{tabular}

MUAC - Mid-upper-arm circumference, BSF - Biceps skinfold, TSF - Triceps skinfold, SSSF - Sub-scapular skinfold, BMI - Body mass index, PBF - Percent body fat, FM - Fat mass, FMI - Fat mass index, FFM - Fat-free mass, FFMI - Fat-free mass index. 
TABLE 2

AGE TRENDS IN ANTHROPOMETRIC AND DERIVED VARIABLES (MEAN \pm SD) OF THE PARTICIPANTS

Age Group (yrs)

\begin{tabular}{|c|c|c|c|c|c|}
\hline \multicolumn{6}{|c|}{ Age Group (yrs) } \\
\hline Variables & $\begin{array}{c}\text { Gr. I: } \\
18-27 \\
(\mathrm{~N}=78)\end{array}$ & $\begin{array}{c}\text { Gr. II: } \\
28-39 \\
(\mathrm{~N}=78)\end{array}$ & $\begin{array}{l}\text { Gr. III: } \\
40-49 \\
(\mathrm{~N}=73)\end{array}$ & $\begin{array}{l}\text { Gr. IV: } \\
\geq 50 \\
(\mathrm{~N}=75)\end{array}$ & $\mathrm{F}$ \\
\hline \multicolumn{6}{|c|}{ Anthropometric variables } \\
\hline Height & $161.8 \pm 5.0$ & $164.0 \pm 4.0$ & $162.2 \pm 6.5$ & $160.8 \pm 5.0$ & $5.083^{*}$ \\
\hline Weight & $51.3 \pm 6.8$ & $51.2 \pm 6.1$ & $49.5 \pm 6.0$ & $46.7 \pm 5.9$ & $9.005^{*}$ \\
\hline MUAC & $24.8 \pm 2.1$ & $24.0 \pm 2.1$ & $23.8 \pm 2.3$ & $23.1 \pm 2.0$ & $8.018^{*}$ \\
\hline $\mathrm{BSF}$ & $3.0 \pm 1.0$ & $2.9 \pm 0.9$ & $2.9 \pm 0.9$ & $2.9 \pm 0.9$ & $0.450^{\mathrm{NS}}$ \\
\hline $\mathrm{TSF}$ & $6.1 \pm 2.9$ & $6.0 \pm 2.2$ & $5.7 \pm 2.0$ & $5.7 \pm 1.9$ & $0.633^{\mathrm{NS}}$ \\
\hline SSSF & $9.4 \pm 3.8$ & $9.1 \pm 3.2$ & $8.2 \pm 2.6$ & $8.8 \pm 3.5$ & $1.907^{\mathrm{NS}}$ \\
\hline \multicolumn{6}{|c|}{ Derived variables } \\
\hline $\mathrm{BMI}$ & $19.5 \pm 2.2$ & $19.0 \pm 2.2$ & $18.8 \pm 2.2$ & $18.0 \pm 2.0$ & $6.316^{*}$ \\
\hline $\mathrm{PBF}$ & $12.4 \pm 2.7$ & $14.4 \pm 2.6$ & $16.4 \pm 2.6$ & $18.4 \pm 2.5$ & $71.378^{*}$ \\
\hline FM & $6.5 \pm 2.3$ & $7.5 \pm 2.3$ & $8.3 \pm 2.4$ & $8.7 \pm 2.2$ & $12.526^{*}$ \\
\hline FMI & $2.4 \pm 0.8$ & $2.8 \pm 0.8$ & $3.1 \pm 0.9$ & $3.3 \pm 0.8$ & $14.262^{*}$ \\
\hline FFM & $44.7 \pm 4.6$ & $43.7 \pm 4.0$ & $41.2 \pm 3.9$ & $38.0 \pm 3.8$ & $39.860^{*}$ \\
\hline FFMI & $17.0 \pm 1.3$ & $16.2 \pm 1.3$ & $15.6 \pm 1.2$ & $14.6 \pm 1.2$ & $43.853^{*}$ \\
\hline
\end{tabular}

${ }^{*}$ Statistically significant at $\mathrm{p}<0.05$; NS - statistically not significant, MUAC - Mid-upper-arm circumference, BSF - Biceps skinfold, TSF - Triceps skinfold, SSSF - Sub-scapular skinfold, BMI - Body mass index, PBF - Percent body fat, FM - Fat mass, FMI - Fat mass index, FFM - Fat-free mass, FFMI - Fat-free mass index.

TABLE 3

BETWEEN/WITHIN AGE GROUP VARIATIONS OF ANTHROPOMETRIC CHARACTERISTICS AMONG THE PARTICIPANTS

\begin{tabular}{|c|c|c|c|c|c|c|}
\hline \multirow{2}{*}{ Variables } & \multicolumn{6}{|c|}{ Age groups } \\
\hline & I vs. II & I vs. III & I vs. IV & II vs. III & II vs. IV & III vs. IV \\
\hline $\mathrm{HT}$ & $-2.221^{\mathrm{NS}}$ & $-0.425^{\mathrm{NS}}$ & $0.993^{\mathrm{NS}}$ & $1.796^{\mathrm{NS}}$ & $3.214^{*}$ & $1.418^{\mathrm{NS}}$ \\
\hline WT & $0.061^{\mathrm{NS}}$ & $1.742^{\mathrm{NS}}$ & $4.594^{*}$ & $1.681^{\mathrm{NS}}$ & $4.533^{*}$ & $2.851^{*}$ \\
\hline MUAC & $0.834^{\mathrm{NS}}$ & $1.037^{*}$ & $1.712^{*}$ & $0.202^{\mathrm{NS}}$ & $0.877^{\mathrm{NS}}$ & $0.674^{\mathrm{NS}}$ \\
\hline BMI & $0.521^{\mathrm{NS}}$ & $0.725^{\mathrm{NS}}$ & $1.517^{*}$ & $0.203^{\mathrm{NS}}$ & $0.995^{*}$ & $0.791^{\mathrm{NS}}$ \\
\hline PBF & $-1.974^{*}$ & $-4.029^{*}$ & $-5.948^{*}$ & $-2.054^{*}$ & $-3.973^{*}$ & $-1.918^{*}$ \\
\hline $\mathrm{FM}$ & $-0.989^{\mathrm{NS}}$ & $-1.745^{*}$ & $-2.164^{*}$ & $-0.755^{\mathrm{NS}}$ & $-1.175^{*}$ & $-0.419^{\mathrm{NS}}$ \\
\hline FMI & $-0.308^{\mathrm{NS}}$ & $-0.666^{*}$ & $-0.873^{*}$ & $-0.358^{\mathrm{NS}}$ & $-0.565^{*}$ & $-0.207^{\mathrm{NS}}$ \\
\hline FFM & $1.051^{\mathrm{NS}}$ & $3.488^{*}$ & $6.759^{*}$ & $2.437^{*}$ & $5.708^{*}$ & $3.271^{*}$ \\
\hline FFMI & $0.830^{*}$ & $1.391^{*}$ & $2.390^{*}$ & $0.561^{\mathrm{NS}}$ & $1.560^{*}$ & $0.999^{*}$ \\
\hline
\end{tabular}

${ }^{*}$ Statistically significant at $\mathrm{p}<0.05$; NS - statistically not significant; HT - Height, WT - Weight, MUAC - Mid-upper-arm circumference, BSF - Biceps skinfold, TSF - Triceps skinfold, SSSF - Sub-scapular skinfold, BMI - Body mass index, PBF - Percent body fat, FM - Fat mass, FMI - Fat mass index, FFM - Fat-free mass, FFMI - Fat-free mass index.

$(-0.276, \mathrm{p}<0.05), \operatorname{MUAC}(-0.277, \mathrm{p}<0.05)$, BMI $(-0.256$, $\mathrm{p}<0.05), \operatorname{FFM}(-0.537, \mathrm{p}<0.05)$ and FFMI $(-0.577, \mathrm{p}<0.05)$ and a positive correlation with $\mathrm{PBF}(0.659, \mathrm{p}<0.05), \mathrm{FM}$ $(0.334, \mathrm{p}<0.05)$ and FMI $(0.354, \mathrm{p}<0.05)$. Similarly, HT had a negative correlation with PBF $(-0.135, \mathrm{p}<0.05)$ and FMI $(-0.124, \mathrm{p}<0.05)$ and a positive correlation with WT $(0.423, \mathrm{p}<0.05)$ and FFM $(0.524, \mathrm{p}<0.05)$.
Table 5 presents the results of the linear regression analysis performed to observe the impact of age on different anthropometric and body composition variables. It can be seen that like in the correlation matrix (Table 4) age had a negatively significant impact on WT $(\mathrm{t}=-4.995$, $\mathrm{p}<0.05)$ MUAC $(\mathrm{t}=-5.016, \mathrm{p}<0.05)$, BMI $(\mathrm{t}=-4.610$, $\mathrm{p}<0.05), \mathrm{FFM}(\mathrm{t}=-11.062, \mathrm{p}<0.05)$ and FFMI $(\mathrm{t}=-12.284$, 
K. Das et al.: Aging, Anthropometry and Body Composition among Kheria Sabar Males, Coll. Antropol. 44 (2020) 2: 73-80

TABLE 4

CORRELATION MATRIX SHOWING ASSOCIATION BETWEEN ANTHROPOMETRIC AND DERIVED VARIABLES

\begin{tabular}{|c|c|c|c|c|c|c|c|c|c|c|c|c|c|}
\hline Variables & Age & HT & WT & MUAC & $\mathrm{BSF}$ & TSF & SSSF & BMI & $\mathrm{PBF}$ & FM & FMI & FFM & FFMI \\
\hline Age & & $-0.08^{\mathrm{NS}}$ & $-0.276^{*}$ & $-0.277^{*}$ & $-0.055^{\mathrm{NS}}$ & $-0.06^{\mathrm{NS}}$ & $-0.09^{\mathrm{NS}}$ & $-0.256^{*}$ & $0.659^{*}$ & $0.334^{*}$ & $0.354^{*}$ & $-0.537^{*}$ & $-0.577^{*}$ \\
\hline $\mathrm{HT}$ & & & $0.423^{*}$ & $0.048^{\mathrm{NS}}$ & $-0.038^{\mathrm{NS}}$ & $0.052^{\mathrm{NS}}$ & $0.008^{\mathrm{NS}}$ & $-0.079^{\mathrm{NS}}$ & $-0.135^{*}$ & $0.078^{\mathrm{NS}}$ & $-0.124^{*}$ & $0.524^{*}$ & $-0.038^{\mathrm{NS}}$ \\
\hline WT & & & & $0.747^{*}$ & $0.474^{*}$ & $0.679^{*}$ & $0.659 *$ & $0.868^{*}$ & $0.438^{*}$ & $0.762^{*}$ & $0.669^{*}$ & $0.944^{*}$ & $0.830^{*}$ \\
\hline MUAC & & & & & $0.458^{*}$ & $0.595^{*}$ & $0.623^{*}$ & $0.796^{*}$ & $0.381^{*}$ & $0.610^{*}$ & $0.595^{*}$ & $0.685^{*}$ & $0.771^{*}$ \\
\hline BFS & & & & & & $0.634^{*}$ & $0.606^{*}$ & $0.543^{*}$ & $0.375^{*}$ & $0.498^{*}$ & $0.504^{*}$ & $0.379^{*}$ & $0.468^{*}$ \\
\hline TSF & & & & & & & $0.816^{*}$ & $0.716^{*}$ & $0.498^{*}$ & $0.689^{*}$ & $0.671^{*}$ & $0.554^{*}$ & $0.614^{*}$ \\
\hline SSSF & & & & & & & & $0.716^{*}$ & $0.478^{*}$ & $0.661^{*}$ & $0.650^{*}$ & $0.542^{*}$ & $0.626^{*}$ \\
\hline BMI & & & & & & & & & $0.558^{*}$ & $0.796^{*}$ & $0.807^{*}$ & $0.751^{*}$ & $0.935^{*}$ \\
\hline $\mathrm{PBF}$ & & & & & & & & & & $0.906^{*}$ & $0.932^{*}$ & $0.124^{*}$ & $0.232^{*}$ \\
\hline $\mathrm{FM}$ & & & & & & & & & & & $0.978^{*}$ & $0.507^{*}$ & $0.542^{*}$ \\
\hline FMI & & & & & & & & & & & & $0.394^{*}$ & $0.544^{*}$ \\
\hline FFM & & & & & & & & & & & & & $0.830^{*}$ \\
\hline FFMI & & & & & & & & & & & & & \\
\hline
\end{tabular}

${ }^{*}$ Statistically significant at $\mathrm{p}<0.05 ; \mathrm{NS}$ - statistically not significant; HT - Height, WT - Weight, MUAC - Mid-upper-arm circumference, BSF - Biceps skinfold, TSF - Triceps skinfold, SSSF - Sub-scapular skinfold, BMI - Body mass index, PBF - Percent body fat, FM - Fat mass, FMI - Fat mass index, FFM - Fat-free mass, FFMI - Fat-free mass index.

TABLE 5

LINEAR REGRESSION ANALYSIS OF AGE WITH ANTHROPOMETRIC AND BODY COMPOSITION VARIABLES OF THE STUDIED POPULATION

\begin{tabular}{lccccccccc}
\hline Variables & $\mathrm{B}$ & $\mathrm{SeB}$ & $\mathrm{Beta}$ & $\mathrm{R}$ & $\mathrm{R}^{2}$ & $\mathrm{Adj} . \mathrm{R}^{2}$ & $\mathrm{t}$ & $\mathrm{Sig}$ \\
\hline HT & -0.206 & 0.139 & -0.085 & 0.085 & 0.007 & 0.004 & -1.485 & 0.139 \\
WT & -0.549 & 0.110 & -0.276 & 0.276 & 0.076 & 0.073 & -4.995 & 0.000 \\
MUAC & -1.589 & 0.317 & -0.277 & 0.277 & 0.077 & 0.074 & -5.016 & 0.000 \\
BMI & -1.475 & 0.320 & -0.256 & 0.256 & 0.066 & 0.063 & -4.610 & 0.000 \\
PBF & 2.459 & 0.162 & 0.659 & 0.659 & 0.434 & 0.432 & 15.219 & 0.000 \\
FM & 1.738 & 0.283 & 0.334 & 0.334 & 0.111 & 0.108 & 6.149 & 0.000 \\
FMI & 4.808 & 0.731 & 0.354 & 0.354 & 0.125 & 0.122 & 6.579 & 0.000 \\
FFM & 1.420 & 0.128 & -0.537 & 0.537 & 0.288 & 0.286 & -11.062 & 0.000 \\
FFMI & 4.717 & 0.384 & -0.577 & 0.577 & 0.333 & 0.331 & -12.284 & 0.000 \\
\hline
\end{tabular}

Statistically significant at $\mathrm{p}<0.05$; HT - Height, WT - Weight, MUAC - Mid-upper-arm circumference, BSF - Biceps skinfold, TSF - Triceps skinfold, SSSF - Sub-scapular skinfold, BMI - Body mass index, PBF - Percent body fat, FM - Fat mass, FMI - Fat mass index, FFM - Fatfree mass, FFMI - Fat-free mass index.

$\mathrm{p}<0.05)$ and a positive impact on $\operatorname{PBF}(\mathrm{t}=15.219, \mathrm{p}<0.05)$, FM $(t=6.149, \mathrm{p}<0.05)$ and FMI $(\mathrm{t}=6.579, \mathrm{p}<0.05)$.

\section{Discussion and Conclusion}

The present study was conducted among 304 apparently healthy adult Kheria Sabar males (aged 18-60 years) of Purulia, West Bengal to estimate the prevalence of undernutrition, to identify possible variations associated with age and to correlate them with relevant anthropometric and body composition parameters. The results of one-way ANOVA test revealed significant $(<0.05)$ associa- tions between all variables of interest across different age groups except for skinfold measurements. For more detailed analysis, Multiple Comparison Test (Schefe's posthoc test) was performed for those variables which were significant in ANOVA to find out between/within age group variation. Both positive and negative significant $(<0.05)$ differences were observed for maximum variables across different age groups. Furthermore, the correlation analysis and simple linear regression analysis were carried out and eventually it was found that with increasing age, PBF (0.659, p<0.05), FM $(0.334, \mathrm{p}<0.05)$ and FMI $(0.354, \mathrm{p}<0.05)$ also increased. 
However, age specific association with skinfolds measurements was not observed in this study. Several studies have reported that the ageing process is closely associated with numerous changes in body composition affecting few anthropometric variables like MUAC, WT and derived variables like BMI, FFM and FFMI, and that it is also associated with a relative loss of subcutaneous adipose tissue and accumulation of adipose tissue in the trunk $\operatorname{area}^{10,14,30}$. One-way ANOVA, Multiple Comparison Test (Scheffe's post-hoc test), linear correlation and regression analysis performed in the present study revealed the same trend in case of FM, FMI and PBF as these variables significantly increased with age. Many studies have shown that PBF and FM increase with age due to a decrease of $\mathrm{FFM}^{31,32}$. However, body composition changes associated with ageing are often found in the absence of weight fluctuations ${ }^{31}$.

In this study both FFM and FFMI demonstrated an antagonistic relationship with age which is in agreement with other global studies on the decline in FFM and FFMI with increasing age ${ }^{15,33-35}$. The probable reason may be sought in sarcopenia, a progressive condition which is related to muscle loss and resulting in disordered energy metabolism, decreased strength and functionality ultimately resulting in malnutrition ${ }^{36-37}$. There are several possible risk factors behind sarcopenia such as excessive alcohol consumption identified by few scholars ${ }^{38-42}$. On the contrary, many studies have also claimed that alcohol consumption does not affect the development of sarcopenia $^{43-45}$. In the context of this study, excessive alcohol consumption was noticed among Kheria Sabar adults of Purulia for hunger suppression and diseases like alcoholic psoriasis were very frequently reported among them. Therefore, we argue that the occurrence of decreasing FFM and FFMI with age in the Kheria Sabar males may be due to alcohol consumption from a very early age.

The present study also showed that the overall prevalence of undernutrition among adult males in this community was $47.6 \%$ (Figure 1). Higher frequency of undernutrition $\left(\mathrm{BMI}<18.5 \mathrm{~kg} / \mathrm{m}^{2}\right)$ was found in $\mathrm{Gr}$. IV: $\geq 50$ years (62.6\%) followed by Gr. II: 28-39 years (48.7\%), Gr. III: 40-49 years (47.9\%) and Gr. I: $18-27$ years (32.0\%). Many recent studies reported a trend in increasing undernutrition among elderly people in comparison to younger people worldwide ${ }^{46-48}$. When our results are compared to some selected global studies conducted recently (mostly in the urban/semi-urban areas) it can be seen that the prevalence of undernutrition found among aged ( $\geq 50$ years) Kheria Sabar males is much higher $(62.6 \%)$ than in the elderly people of Taiwan $(20.2 \%)^{48}$, Lebanon $(7.6 \%)^{49}$, China $(8.0 \%)^{50}$, Bangladesh $(26.0 \%)^{51}$, Iran $(11.5 \%)^{52}$, Africa $(19.2 \%)^{47}$, Southern-India $(17.9 \%)^{23}$ or Northern-India $(53.7 \%)^{53}$. Furthermore, the overwhelming majority of tribal communities of India live in rural and forest areas and the frequency of undernutrition among them is much higher irrespective of all age groups and gender than in their urban counterpart. A high prevalence of undernutrition among tribal elderly males was also reported by another study in 2005 covering nine states in India which

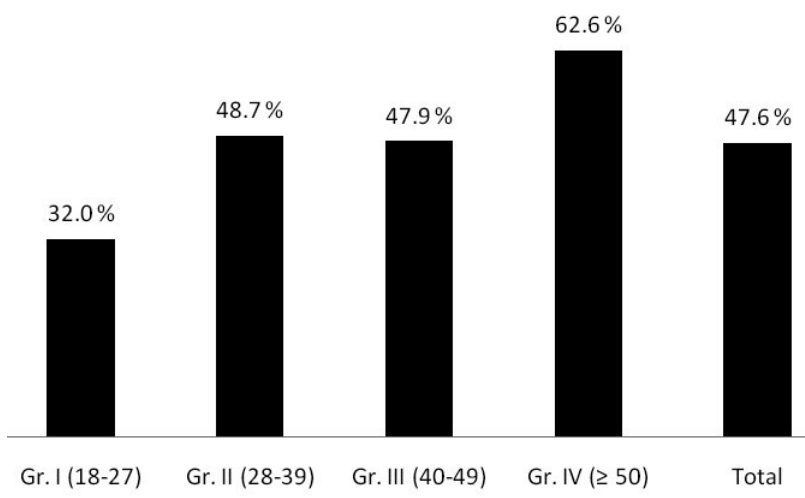

Fig.1. Age-wise distribution of undernutrition among the studied population.

revealed that $61.8 \%$ of this population was affected by undernutrition ${ }^{54}$. The comparison with similar studies on different tribal communities also reveals that the mean BMI of aged Kheria Sabar males $\left(18.0 \mathrm{~kg} / \mathrm{m}^{2}\right)$ is in agreement with that of the Bathudis of Orissa $\left(17.8 \mathrm{~kg} / \mathrm{m}^{2}\right)^{22}$ and Santals of Purulia $\left(18.2 \mathrm{~kg} / \mathrm{m}^{2}\right)^{9}$.

As a result of a limited number of studies on undernourished older tribal people in India, nutritional problems remain unrecognized and untreated till today, and this study has emanated from this apparent dearth of knowledge in this domain. Undernutrition can be a direct effect of multiple factors both biological and social. While adaptation and nutritional absorption from food sources may be attributed to the individual genetic makeup, the availability of food and the necessary livelihood opportunities to cater to that availability are mostly dependent on policy. Indigenous people mostly are at the wrong end of both the parameters due to their harsh habitat and social isolation from developed regions. Thus, epidemiological and cognitive data are mostly available as academic discourses while the ageing population is mostly neglected due to their unsuitability for livelihood generation. However, from ethnographic and evolutionary standpoints they represent very important data sources, now even more significant due to the recent reemergence of infectious diseases due to unwarranted recombination events (COVID-19) or permafrost melting as a result of global warming. Thus this work creates a small ripple into the uncharted depths of age associated undernutrition among elderly adults and charts a path to stimulate studies in this twilight zone on our planet in general and India in particular.

Since older people are more vulnerable to malnutrition particularly among the poverty-stricken sections of the population, the findings of this study emphasize the need to provide several nutritional interventions among the elderly section of a vulnerable community to enable them to procure essential nutrients and encounter their nutritional needs. However, it must be mentioned that there are some limitations of the present study due to its cross-sectional design based on small sample size of only male participants; therefore, strong conclusions about risk factors 
or causal relationships among variables may not be reached, though, defining important determinants of nutritional status primarily depends on a number of events not on the sample size. As the population sample was ethnically homogenous in nature the findings of this study may be used to formulate larger confirmatory studies in future. To further correlate the problems of undernutrition with epidemiological, social and cognitive aspects of ageing among the elderly tribal people further studies on different tribal communities across different habitats are urgently needed particularly in the wake of the pandemic outbreak of COVID19 and its unknown effect on the elderly indigenous people in general, and India in particular.

\section{Declaration of Interest}

None declared.

\section{R E F E R E N C E S}

1. JACKSON AA, JOHNSON M, DURKIN K, WOOTTON S, Eur J Clin Nutr, 67 (2013) S71. - 2. CAMPOS I, KONTAKO P, Assessment of Fluid Status and Body Composition and Control of Fluid Balance with Intermittent Hemodialysis in the Critically Ill Patients. In: RONCO C, BELLOMO R, KELLUM JA, RICCI Z (Eds) Critical Care Nephrology (Elsevier, London, 2019). - 3. KURIYAN R, Indian J Med Res, 148 (2018) 648. - 4. BRODIE D, MOSCRIP V, HUTCHEON R, Nutrition, 14 (1998) 296. - 5. LOHMAN TG, Hum Biol, 53 (1981) 181. - 6. ROCHE AF, Anthropometry and ultrasound. In: ROCHE AF, HEYMSFIELD SB, LOHMAN TG (Eds) Human Body Composition (Human Kinetics, Cham paign, IL, 1996). - 7. WEINER JS, LOURIE JA, Practical human biology. (Academic Press, London, New York, 1981). - 8. BOSE K, CHAKRABORTY F, Asia Pac J Clin Nutr, 14 (2005) 80. - 9. DAS S, BOSE K, Coll Antropol, 36 (2012) 581. - 10. SCHWARTZ RS, SHUMAN WP, BRADBURY VL, CAIN KC, FELLINGHAM GW, BEARD JC, KAHN SE, STRATTON JR, CERQUEIRA MD, ABRASS IB, J Gerontol, 45 (1990) M181. - 11. VANITALLIE TB, YANG MU, HEYMSFIELD SB, FUNK RC, BOILEAU RA, Am J Clin Nutr, 52 (1990) 953. - 12 DEURENBERG P, WESTSTRATE JA, SEIDELL JC, Br J Nutr, 65 (1991) 105. - 13. HEYMSFIELD SB, WANG ZM, WITHERS RT, Multicomponent molecular level models of body composition. In: ROCHE AF, HEYMSFIELD SB, LOHMAN TG (Eds) Human Body Composition (Human Kinetics, Champaign, IL, 1996). - 14. CASO G, MCNURLAN MA, MILEVA I, ZEMLYAK A, MYNARCIK DC, GELATO MC, Metabolism, 62 (2013) 337. - 15. KYLE UG, GENTON L, HANS D, KARSEGARD L, SLOSMAN DO, PICHARD C, Eur J Clin Nutr, 55 (2001) 663. - 16. WULAN SN, WESTERTERP KR, PLASQUI G, Maturitas, 65 (2010) 315. - 17. HE X, LI Z, TANG X, ZHANG L, WANG L, HE Y, JIN T, YUAN D, Medinice, 97 (2018) e11152. - 18. RAMJI S, Indian Pediatr, 38 (2001) 263. - 19. DAS K, BAGCHI SS, PAL S, GANGULI S, MUKHERJEE K, Hum Bio Rev, 8 (2019) 316. - 20. PATIL YP, SHINDE RL, Am J Mens Health, 8 (2014) 492. - 21. DAS S, BOSE K, Anthrop Rev, 78 (2015) 47. - 22. BOSE K, BISAI S, CHAKRABORTY F, Coll Antropol, 30 (2006) 771. - 23. KRISHNAMOORTHY Y, VIJAYAGEETHA M, KUMAR SG, RAJAA S, REHMAN T, J Family Med Prim Care, 7 (2018)1429. - 24. KSHATRIYA GK, ACHARYA SK, Plos One, 11(2016) e0147934. - 25. GHOSH SK, GUCHHAIT SK, IOSR-JHSS, 22 (2017) 72. - 26. SRIVASTAVA A, The Criminal Tribes of India (Mohit Book International, New Delhi, 2011). - 27. ULIJASZEK SJ, KERR DA, Br J Nutr, 82 (1999) 165. - 28. LOHMAN TG, Advances in body composition assessment (Human Kinetics, Champaign, 1992). - 29. WORLD
HEALTH ORGANIZATION/INTERNATIONAL OBESITY TASK FORCE: The Asia-Pacific perspective: redefining obesity and its treatment. (Health Communications, Sydney, Australia, 2000). - 30. SHIMO KATA H, TOBIN JD, MULLER DC, ELAHI D, COON PJ, ANDRES R, J Gerentol, 44 (1989) M66. - 31. ST-ONGE MP, GALLAGHER D, Nutrition, 26 (2010) 152. - 32. JAFARINASABIAN P, INGLIS JE, REILLY W, KELLY OJ, ILICH JH, J Endocrinol, 234 (2017) 37. - 33. OBISESAN TO, ALIYU MH, BOND V, ADAMS RG, AKOMOLAFE A, ROTIMI CN, BMC Public Health, 5 (2005) 41. - 34. ATLANTIS E, MARTIN SA, HAREN MT, TAYLOR AW, WITTERT GA, Am J Clin Nutr, 88 (2008) 95. - 35. SONATI JG, MODENEZE DM, VILARTA R, MACIEL ES, BOCCALETTO EM, Maturitas, 68 (2011) 378. - 36. ROSENBERG IH, Clin Geriatr Med, 27 (2011) 337. - 37. CAMPBELL TM, VALLIS LA, Age (Dordr), 36 (2014) 9674. - 38. CASTILLO EM, GOODMAN-GRUEN D, KRITZ-SILVERSTEIN D, MORTON DJ, WINGARD DL, BARRETTCONNOR E, Am J Prev Med, 25 (2003) 226. - 39. LAU EM, LYNN HS, WOO JW, KWOK TC, MELTON LJ, J Gerontol A Biol Sci Med Sci, 60 (2005) 213. - 40. KIM SH, KIM TH, HWANG HJ, Arc Gerontol Geriatr, 56 (2013) 472. - 41. YOO JI, HA YC, LEE YK, HANA-CHOI, YOO MJ, KOO KH, BMC Geriatr, 17 (2017) 114. - 42. KWON YJ, LIM HJ, LEE YJ, LEE HS, LINTON JA, LEE JW, H. T. KANG HT, Menopause, 24 (2017) 1022. - 43. BOFETTA P, GARFINKEL L, Epidemiology, 1 (1990) 342. - 44. KANNEL WB, ELLISON RC, Clinica Chimica Acta, 246 (1996) 59. - 45. STEFFL M, BOHANNON RW, PETR M, KOHLIKOVA E, HOLMEROVA I, BMC Geriatr, 16 (2016) 99. - 46. BERNSTEIN M, MUNOZ N, J Acad Nutr Diet, 112 (2012) 1255. - 47. JESUS P, GUERCHET M, PILLERON S, FAYEMENDY P, MAXIME MOUANGA A, MBELESSO P, PREUX PM, DESPORT JC, Clin Nutr ESPEN, 21 (2017) 40. - 48. PODA GG, HSU CY, RAU HH, CHAO JC, Nutr Res Pract, 13 (2019) 222. - 49. BOULOS C, SALAMEH P, BARBERGER-GATEAU P, BMC Public Health, 35 (2016) 138. - 50. HAN Y, LI S, ZHENG Y, Public Health Nutr, 12 (2009) 1189. - 51. FERDOUS T, KABIR ZN, WAHLIN A, STREATFIELD K, CEDERHOLM T, Public Health Nutr, 9 (2006) 968. - 52. MOKHBER N, MAJDI M, ALI-ABADI M, SHAKERI M, KIMIAGAR M, SALEK R, MOGHADDAM PA, SAKHDARI A, AZIMI-NEZHAD M, GHAOUR-MOBARHAN M, SOLUTI S, Iran J Public Health, 40 (2011) 67. - 53. JAMIR L, KALAIVANI M, NONGKYNRIH B, MISRA P, GUPTA SK, Asia Pac J Public Health, 27 (2015) 2246. - 54. ARLAPPA N, BALAKRISHNA N, BRAHMAM GN, VIJAYARAGHAVAN K, J Nutr Elder, 25 (2005) 23.

\section{K. Das}

Department of Anthropology, Bangabasi College, Kolkata 700 009, India e-mail: kaustavanthro@gmail.com 


\section{DOBNE VARIJACIJE U ANTROPOMETRIJI, SASTAVU TIJELA I PREHRAMBENOM STATUSU U MUŠKOJ POPULACIJI KHERIA SABAR U PURULIJI, ZAPADNI BENGAL}

\section{S A Ž E T A K}

Pothranjenost i starenje mogu znatno utjecati na sastav tijela. Cilj ove transverzalne studije je istraživanje dobnih varijacija u antropometrijskim vrijednostima i sastavu tijela u muškoj populaciji Kheria Sabar iz pokrajine Purulia u Zapadnom Bengalu u Indiji.. Slučajni uzorak uključio je 304 zdrava, odrasla muškarca u dobi između 16 i 80 godina iz 15 sela u pokrajini, koji su podijeljeni u četiri dobne skupine. Prikupljene su standarne antropometrijske mjere: visina (HT), težina (WT), opseg nadlaktice (MUAC) i kožni nabori bicepsa (BSF), tricepsa (TSF) i na leđima (SSSF). Izračunate su varijable indeksa tjelesne mase (BMI) i postotka masnog tkiva (PBF) te masna tjelesna masa (FM) i nemasna tjelesna masa (FFM) i odgovarajući indeksi (FMI i FFMI). Većina varijabli bila je u negativnoj korelaciji sa dobi. Utvrđene su statistički značajne pozitivne (HT, WT, MUAC, BMI, FFM and FFMI) i negativne (FM and FMI) razlike između dobnih skupina. Ukupna prevalencija pothranjenosti iznosila je $47,6 \%$, a najviša je bila u najstarijoj dobnoj skupini $(62,6 \%)$. Rad jasno pokazuje da je rizik od malnutricije najveći u starijoj populaciji i da je u tom smislu potrebno poduzeti intervencijske mjere. 